\title{
Correction to: Actual survival after resection of primary colorectal cancer: results from a prospective multicenter study
}

Inge van den Berg ${ }^{*}$, Robert R. J. Coebergh van den Braak, Jeroen L. A. van Vugt, Jan N. M. ljzermans and Stefan Buettner

\section{Correction to: World J Surg Onc 19, 96 (2021) https://doi.org/10.1186/s12957-021-02207-4}

Following publication of the original article [1], the authors reported that there was an error in reference 30.

Currently it reads:

Charlotte KDD, Cornelis J, Petur S, Johannes C, Arend A, Bemelman WA, et al. Adjuvant HIPEC in patients with colon cancer at high risk of peritoneal metastases: Primary outcome of the COLOPEC multicenter randomized trial. J Clin Oncol. 2019;37:482.

It should read:

Klaver CEL, Wisselink DD, Punt CJA, Snaebjornsson P, Crezee J, Aalbers A, et al. Adjuvant HIPEC in patients with colon cancer at high risk of peritoneal metastases: Primary outcome of the COLOPEC multicenter randomized trial. J Clin Oncol. 2019;37:482.

Additionally, a minor change in the abstract has been made and Figure 2I and 2J has been updated with the better resolution figure.

The Original article has been updated.

Published online: 26 May 2021

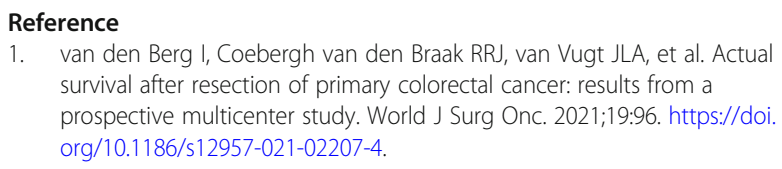

The original article can be found online at https://doi.org/10.1186/s12957021-02207-4.

* Correspondence: i.vandenBerg@erasmusmc.nl

Department of Surgery, Erasmus MC - University Medical Center Rotterdam,

Rotterdam 3015 GD, The Netherlands

(c) The Author(s). 2021 Open Access This article is licensed under a Creative Commons Attribution 4.0 International License, which permits use, sharing, adaptation, distribution and reproduction in any medium or format, as long as you give appropriate credit to the original author(s) and the source, provide a link to the Creative Commons licence, and indicate if changes were made. The images or other third party material in this article are included in the article's Creative Commons licence, unless indicated otherwise in a credit line to the material. If material is not included in the article's Creative Commons licence and your intended use is not permitted by statutory regulation or exceeds the permitted use, you will need to obtain permission directly from the copyright holder. To view a copy of this licence, visit http://creativecommons.org/licenses/by/4.0/. The Creative Commons Public Domain Dedication waiver (http://creativecommons.org/publicdomain/zero/1.0/) applies to the data made available in this article, unless otherwise stated in a credit line to the data. 